\title{
Is it possible to teach English through EBA TV? Exploring student teachers' concerns and self-efficacy beliefs
}

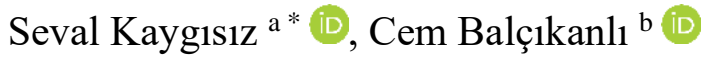 \\ ${ }^{a}$ Gazi University, English Language Teaching Program, Ankara, Turkey. \\ ${ }^{\mathrm{b}}$ Gazi University, English Language Teaching Program, Ankara, Turkey.
}

Suggested citation: Kaygısız, S. \& Balçıkanlı, C. (2021). Is it possible to teach English through EBA TV? Exploring student teachers' concerns and self-efficacy beliefs. Journal of Educational Technology \& Online Learning, 4(3), 489-502.

\begin{tabular}{l} 
Article Info \\
\hline Keywords: \\
Emergency remote teaching \\
EBA TV \\
Second language teacher \\
education \\
Self-efficacy beliefs \\
Teacher concern \\
The Covid-19 pandemic
\end{tabular}

Research Article

\begin{abstract}
This qualitative study explored student teachers' perceptions and feelings about teaching English in an emergency remote teaching platform, Educational Information Network TV. To this end, sixty-eight student teachers participated in this study. The participants were first invited to watch English language courses specifically designed for primary and secondary-level education provided through this medium of instruction. They were later asked to write two-page reflective journals on the strengths and weaknesses of these courses drawing upon their own feelings and opinions. Their written reflections were content analyzed, and the findings revealed two main themes: student teachers' concerns and self-efficacy beliefs. More specifically, the student teachers were concerned about macro-level factors, pedagogical issues, teachers' competencies, and context-dependent factors. Additionally, the findings shed light on the contributing factors to their selfefficacy beliefs. They attributed their future success to student-oriented factors, teacheroriented factors, and parental involvement. The overall findings showed that their concerns outweighed their perceived self-efficacy beliefs. We hope that these findings will inform second language teacher education programs for the future since it could be of pivotal importance to prepare student teachers for distance or online learning platforms by helping them deal with their concerns and enriching their self-efficacy beliefs in their own teaching contexts.
\end{abstract}

\section{Introduction}

In Turkey, as in many other countries, the Covid-19 pandemic has called for a sudden paradigm shift from face-to-face education to emergency remote teaching. Emergency remote teaching offers "temporary access to instruction and instructional supports in a manner that is quick to set up and is reliably available during an emergency or crisis" (Hodges et al., 2020, p. 6). Additionally, it requires using different strategies and approaches, in which learners are enmeshed into learning as an "obligation" (Bozkurt \& Sharma, 2020, p. ii). Succinctly, it helps to sustain education outside the traditional classrooms, especially during such troublesome moments. Accordingly, as an emergency remote teaching platform, Educational Information Network TV (EBA TV, henceforth) started broadcasting on March 23, 2020 in Turkey.

EBA TV is run by the Turkish Ministry of National Education (MoNE) in collaboration with the Turkish Radio and Television Corporation [Türkiye Radyo Televizyon Kurumu, TRT] and provides courses specifically designed for primary, secondary, and high school education. Instructional materials, course

\footnotetext{
* Seval Kaygisız. English Language Teaching Program, Gazi University, Turkey. e-mail address: sevalkaygisiz@gmail.com
} 
content, teaching methods, and techniques have been tailored accordingly to benefit from such an educational platform. Nevertheless, it might have come with a few challenges for language teachers. Within this framework, this sudden change necessitates exploring English language student teachers' feelings and opinions to amplify opportunities for the necessary guidance and support for the future and prepare student teachers better to teach in distance or online teaching platforms no matter whether a sudden paradigm shift is obligatory or not.

It is necessary to be cognizant of student teachers' feelings to promote both professional and personal dimensions in teacher education. That said, emphasizing these both dimensions will "contribute to educational goals that go far beyond the development of the individual teacher" (Meijer et al., 2009, p. 308) since good teachers are more than "well-oiled machines" (Hargreaves, 1998, p. 835) and "certain isolated competencies" (Korthagen, 2004, p. 79). Therefore, this study attempts to portray student teachers' opinions and feelings about teaching English through an emergency remote teaching platform in general and unveil their concerns and self-efficacy beliefs in particular.

\section{Literature Review}

\section{Teacher Concern}

Teaching is "an emotional practice" (Hargreaves, 2000, p. 824). Understanding teacher concern thus is the main impetus behind scaffolding student teachers to deal with their prominent concerns and fostering their professional development as well as enriching their personal beliefs before they embark on the teaching profession (O’Connor \& Taylor, 1992; Guillaume \& Rudney, 1993; Poulou, 2007). In this sense, Fuller's (1969) concerns-based model has acted as a catalyst, for the first time, in understanding and sifting through teachers' concerns in their professional careers. According to the model, all the teachers pass through the same developmental stages: self-concerns, task-related concerns, and impact concerns, respectively (Fuller et al., 1974; Boz, 2008). More specifically, self-concern is related to teachers' ideas about their own competencies and survival skills in the classroom as well as receiving positive comments from others; taskrelated concern refers to their worries about the teaching task itself such as teaching methods, insufficient classroom time, and lack of materials; and, impact concern addresses teachers' concerns about meeting their students' social, and emotional needs (Fuller, 1969; Fuller et al., 1974; Reeves \& Kazelskis, 1985; Swennen et al., 2004). Three stages follow a linear pattern; as such, once self-concerns are resolved, teachers develop task-related concerns and then impact concerns (Reeves \& Kazelskis, 1985). However, the duration of the stages differs among the teachers (Boz, 2008). Some scholars provide further evidence regarding this linear view of developmental stages (e.g., Fuller \& Bown, 1975; Butler \& Smith, 1989). Nevertheless, many scholars run counter to this view by advocating the simultaneous development of multiple teacher concerns (Reeves \& Kazelskis, 1985; Guillaume \& Rudney, 1993; Pigge \& Marso, 1997; Boz, 2008). They further argued the complexity of the development of student teachers' high level of concerns (Burn et al., 2003).

Fuller's model could also describe student teachers' concerns (Fuller, 1969). However, as to the distinction between student teachers' and in-service teachers' development of concerns, Fuller and her colleagues (1974) put forward that student teachers develop more self-concerns whereas in-service teachers develop more impact concerns. Based on this model, an array of research studies has attempted to probe student teachers' concerns about the teaching profession in the field of teacher education (e.g., Guillaume \& Rudney, 1993; Burn et al., 2003; Swennen et al., 2004; Poulou, 2007; Boz, 2008; Boz \& Boz, 2010). These studies have been carried out in different countries and in various teacher education programs such as primary school teacher education (e.g., Swennen et al., 2004), elementary education (e.g., Guillaume \& Rudney, 1993; Poulou, 2004), secondary science, and mathematics education (e.g., Boz \& Boz, 2010). Besides, studies have examined teachers' concerns in traditional classrooms. More recently, Farmer and West (2019) have explored teachers' concerns in online learning environments. They have indicated that 
both teacher education programs and online teaching organizations should address teachers' concerns such as lack of autonomy over the course content and then relieve their concerns accordingly. Building on this previous literature, the present study aims to depict student teachers' concerns in a second language teacher education program by specifically drawing upon their feelings about an emergency teaching platform instead of traditional classrooms in addition to their self-efficacy beliefs. The importance of teacher selfefficacy beliefs is fleshed out below.

\section{Teacher Self-Efficacy Beliefs}

Self-efficacy is rooted in Bandura's social cognitive theory predicated on "an agentic perspective in which individuals are producers of experiences and shapers of events" (Bandura, 2000, p. 75). Self-efficacy belief is delineated as "people's judgments of their capabilities to organize and execute courses of action required to attain designated types of performances" (Bandura, 1986, p. 391). Whereas capability addresses having essential skills to carry out a specific task, what matters is one's belief in their capability to perform well in this task. Individuals with higher self-efficacy beliefs, holding a stronger faith to succeed, might perform better than those with a higher capability but with lower self-efficacy beliefs (Williams \& Burden, 1997). Besides, those with higher self-efficacy beliefs are construed as more self-regulated, more positive, and more persistent or resilient when faced with a challenge (Usher \& Schunk, 2018). In this sense, since the teaching profession is grappled with complexity, stress, and challenges, understanding teachers' selfefficacy beliefs might pave the way for providing them with the necessary guidance and support in teacher education programs (Gibbs \& Miller, 2004).

Teacher self-efficacy beliefs refer to "teachers' evaluation of their abilities to bring about positive student change" (Gibson \& Dembo, 1984; p. 570). Previous research indicated that teachers' self-efficacy beliefs affect their students' achievement (Aston, 1984), leaving the teaching profession (Glickman \& Tamashiro, 1982; Hong, 2012); commitment to their job (Coladarci, 1992); burn-out (Brouwers \& Tomic, 2000); students' resilience (Sosa \& Gomez, 2012); preferred teaching styles (Heidari et al., 2012); collaboration with parents (Hoover-Dempsey et al., 1987; 1992); job satisfaction (Demir, 2020; Kasalak \& Dağyar, 2020); and teaching concerns (Boz \& Boz, 2010). Among these studies, Boz and Boz (2010) investigated the relationship between student teachers' concerns and self-efficacy beliefs, and they found that those with higher self-efficacy beliefs had less concerns about teaching.

Self-efficacy belief is construed as more than a stable trait. As such, Bandura (2012) acknowledges that self-efficacy beliefs "vary across activity domains and situational conditions rather than manifest uniformly across tasks and contexts in the likeness of a general trait" (p. 13). In a meta-analysis on teachers' selfefficacy beliefs, Kasalak and Dağyar (2020) further articulate that their beliefs might even vary according to their access to technology and information over the years. Thus, we believe that exploring student teachers' concerns and efficacy beliefs about teaching English through a remote teaching platform merits further attention.

\section{Emergency Remote Teaching of English Language}

As previously explained, emergency remote teaching is defined as "a temporary shift of instructional delivery to an alternate delivery mode due to crisis circumstances" (Hodges et al., 2020, p. 6). Since the Covid-19 pandemic was an unexpected phenomenon, language teachers having little or no experience in distance or online teaching beforehand might have encountered various challenges during this sudden transition. In this sense, several studies have attempted to examine these challenges. For instance, Atmojo and Nugroho (2020) analyzed sixteen Indonesian English language teachers' experiences during the pandemic, and they indicated challenges such as, inter alia, technological constraints, students' low digital literacy and lack of motivation, late submission of the assignments, and "teachers' lack of experience and knowledge" (p. 66) as well as their "lack of preparation and readiness" (p. 67) in online learning. Similarly, Bailey and Lee (2020) probed English language instructors' perceived challenges and benefits of 
emergency remote teaching and indicated that novice teachers experienced a lack of preparation for online teaching. They further stressed the importance of developing teachers' online teaching competencies.

In another study, Todd (2020) similarly searched teachers' perceptions about the transition to emergency remote teaching and found that this transition provided affordances such as flexibility in time and students' taking the responsibility for their own learning. Nevertheless, they addressed several constraints such as technological problems, checking students' reactions and understanding, and practicing speaking skills in pairs. More recently, Hazaea et al. (2021) examined university instructors' challenges and similarly found technological constraints and pedagogical challenges such as student engagement and assessment, lack of real communication, preparing appropriate materials, and adopting the necessary teaching strategies. These findings were also echoed in Erarslan (2021), who reviewed sixty-nine studies examining English language teaching during the emergency remote teaching process. Accordingly, this process brought several challenges such as technological problems like internet connection and access to smartphones or computers and teachers' lack of preparation and "insufficient technological and pedagogical content knowledge" (p. 359) even though it facilitated teachers' development of digital literacy skills.

Building on this line of research, the present study is expected to contribute to the literature in several ways. First of all, as seen from the findings above, student teacher preparation is of pivotal importance in order not to be caught off guard once again in an emergency, if any. Secondly, student teachers reflected on their own opinions, perceptions, and feelings about the conceptualization of remote teaching. Therefore, their reflections might contribute to the amelioration of the second language teacher education program in Turkey. Thirdly, all the participants watched specific pre-recorded lessons, and thus it might be easier to compare their feelings. Fourth, they reflected on not their own learning and teaching experience but evaluated others' teaching performance as an outsider, so their self-efficacy beliefs and concerns appeared more naturally. At the heart of this descriptive study thus were two research questions:

1. What are the student teachers' concerns about teaching English through EBA TV?

2. What are their perceived self-efficacy beliefs in teaching English through this remote teaching platform?

\section{Methodology}

\subsection{Data Collection}

This qualitative study adopts a case study design which offers "an intensive description and analysis of a phenomenon or social unit such as an individual, group, institution, or community." (Merriam, 2002, p. 8). The data were collected through written reflective journal entries to reveal participants' feelings, concerns, worries, and internal thoughts that "may be inaccessible from the researcher's perspective alone" (Mackey $\&$ Gass, 2005, p. 178). The student teachers were assigned to watch three different English lessons specifically designed for primary (third grade and fourth grade) and secondary-level (seventh grade) education (links to these three sessions were provided in Appendix A). These lessons were selected based on three criteria: i) they were representative in terms of variety of activities such as games and songs, ii) there were critical points for student teachers to reflect upon, and iii) the topics were interesting and familiar (transportation, clothes, and public buildings). The student teachers were later asked to write two-page written reflections on their opinions and feelings about the English classes broadcasted on EBA TV (they were free to watch more than three lessons). They were specifically asked to reflect on their perceptions and feelings about the strengths of the classes and the points that need to be improved. Finally, they uploaded their papers on Google Classroom, which facilitated the learning and sharing process throughout the semester. 


\subsection{Study Group}

This study was carried out at a state university in Ankara, Turkey with a total of 68 student teachers. They were second-year $(n=50)$ and third-year $(n=18)$ students enrolled in a four-year Bachelor of Arts Program in English Language Teacher Education. There were 43 females and 25 males, and their ages ranged between 19 to $52(M=21,23)$. Data were collected at the end of the Spring semester of the 2019-2020 academic year. At the time of the data collection, the participants were taking a compulsory second-year course in the program titled 'Language Acquisition' which covers the theoretical underpinnings of first and second language acquisition. The second graders were also taking a methodological course named 'English Language Teaching Methodology I', and the third graders were taking 'ELT Methodology II' and 'Teaching Language Skills I' at the same time. As a requirement of these courses, they were presenting micro-lessons to their classmates, but they had very little or no real classroom teaching experience. The participants were selected purposefully for the study based on two criteria: i) they provided clear and detailed reflections on their feelings about distance education, and ii) they agreed that their papers could be used for research purposes. The disclosure of the identity of the participants was taken into consideration for the present study.

\subsection{Data Analysis}

The reflective journals were content analyzed (Krippendorff, 2018) by following these steps: i) reading the journals repeatedly to gain a general understanding and identifying the initial codes, ii) determining the recurring codes and categories, iii) making links between them to identify the main themes. First of all, the researchers read the data repeatedly and coded the data individually. Then, we worked together, discussed the initial codes and identified 35 codes. To ensure inter-coder reliability, we negotiated the codes and categories until there was a full agreement and combined seven codes with other relevant codes in the pool. A total of 28 codes were provided below. Later, the first researcher discussed the recurring codes and categories with another researcher holding a doctoral degree in the field, and she suggested only a few changes in terms of word choice. We used MAXQDA (version 20.1.0), computer software for the qualitative analysis, to facilitate the process of data analysis, calculate the frequencies, store the data, and retrieve excerpts from the data based on the themes.

\subsection{Findings and Discussion}

The findings from the written reflections revealed two main themes: student teachers' concerns and their self-efficacy beliefs. The distribution of the data was provided according to the number of the participants. In other words, the number of participants was considered rather than the frequency of their repetitive statements.

Concerns: "We cannot teach English successfully..."

The overall findings indicated that more than half of the student teachers approached teaching English via EBA TV with trepidation. They firmly pointed out that it was impossible to teach English successfully, and they were expecting to be back in the traditional classrooms. More specifically, their concerns were related to four categories: i) macro-level factors, ii) pedagogical issues, iii) teachers' competencies, and iv) contextdependent factors. The distribution of the codes and categories about their concerns was provided in Table 1 below. 


\section{Table 1.}

The distribution of the codes and categories and themes related to teacher concern

\begin{tabular}{|c|c|c|c|}
\hline Themes & Categories & Codes & $\begin{array}{l}\text { The } \\
\text { number } \\
\text { of STs } \\
\text { (68) }\end{array}$ \\
\hline \multirow{20}{*}{ Concerns } & \multirow[t]{3}{*}{ Macro-level factors } & Limited classroom hours & 16 \\
\hline & & Constraints in measurement & 5 \\
\hline & & Insufficient response time for students & 3 \\
\hline & \multirow[t]{10}{*}{ Pedagogical issues } & Having limited social interaction & 38 \\
\hline & & Checking students' understanding & 26 \\
\hline & & Drawing students' attention & 24 \\
\hline & & Monitoring active participation & 19 \\
\hline & & Limited comprehension due to use of target language only & 16 \\
\hline & & Providing immediate feedback & 14 \\
\hline & & Developing speaking skills & 12 \\
\hline & & Receiving feedback from students & 11 \\
\hline & & Teachers monitoring themselves & 7 \\
\hline & & Noticing students' emotions & 4 \\
\hline & \multirow{3}{*}{$\begin{array}{l}\text { Teachers' } \\
\text { competencies }\end{array}$} & Making pronunciation mistakes & 8 \\
\hline & & Displaying digital literacy & 6 \\
\hline & & Integrating four skills & 5 \\
\hline & \multirow{4}{*}{$\begin{array}{l}\text { Context-dependent } \\
\text { factors }\end{array}$} & Learning in a distracting environment & 16 \\
\hline & & Students' technological constraints & 14 \\
\hline & & Students' unfamiliarity with this mode of learning & 10 \\
\hline & & Parents' negative attitudes towards learning & 3 \\
\hline
\end{tabular}

The findings demonstrated the student teachers' concerns about macro-level factors referred to organizational planning of the courses. To be more precise, each class lasted between twenty and twentyfive minutes, and several student teachers $(n=16)$ pointed out that time limitation negatively impacted the effectiveness of the courses and caused teachers to act quickly and speak fast:

"Because of this limit, it becomes more challenging for teachers. It should be extended a little bit in order to let teachers teach English lessons more effectively." (Ela)

Some of them $(n=3)$ also expressed that this time limitation led to insufficient response time for students since teachers waited only a little bit after asking questions:

"Teachers are quite fast, and they just wait for two seconds and give the answer. Although we are all aware that there is a time limit for every lesson, I feel like students struggle to keep up the pace with their teacher." (Zeynep)

On the other hand, a few student teachers $(n=3)$ favored time limitation in terms of students' concentration span and one of them expressed that:

"Since teachers are restricted with a time limit, they get fully prepared before the lesson starts and they put a great effort while teaching." (Ersin)

In addition, some student teachers $(n=5)$ highlighted the importance of measuring students' progress and attributed students' success to the measurement and evaluation:

"They [teachers] cannot evaluate the students' outcome. As long as we cannot see the outcome or evaluate it, I think we cannot call it learning." (Neslihan)

The findings indicated that several student teachers $(n=12)$ were concerned about the lack of opportunities for developing speaking skills. They voiced that language learning could not take place unless learners produced. One of them stated that: 
"Language cannot be learned by watching the lessons, so there will possibly be deficiencies in using the language. Distance education can be improved, but again it will never be as efficient as in school." (Gizem)

Besides, sixteen student teachers commented negatively on using only the target language as the medium of courses and claimed that it could lead to a lack of comprehension for students. In other words, students could not follow the instructions, and they might feel confused or demotivated since they were mostly being exposed to their mother tongue in their traditional classrooms:

"...considering the fact that most of the teachers use Turkish in their classrooms, it must be hard for the students to get used to an English spoken lesson. Thus, students may get bored, lose their interests and don't want to listen to the teacher." (Neşe)

Factors related to pedagogical issues stemmed from the problems caused by the physical distance. A great majority of student teachers $(n=38)$ articulated that it was nearly impossible to teach English through EBA TV due to limited social interaction. They claimed that English classes were teacher-centered and learners were passive. Besides, there was no student-student or student-teacher interaction, and students had no chance to ask questions when they encountered problems:

"I think that it can never be good as the learning that conducted with physical face to face interaction especially in English context where interaction and socialization have huge importance. Without good interaction, we cannot create a suitable social context to teach English." (Ahmet)

Furthermore, the student teachers noted that it was quite challenging to check students' understanding, draw their attention, monitor their active participation, and notice students' feelings and emotions. Some of them stated that a relaxing and stress-free learning environment might cause students to lose their interest quickly. Thus, they believed in the necessity of an authority to encourage their active participation:

“Taking the students' attention is a challenging job. In distance education, it is much harder because there is no authority to control students whether they are listening carefully or not." (Emre)

Besides, only a small number of student teachers underscored the facilitative role of parents in motivating and monitoring students and developing their autonomy. They also stressed the importance of providing $(n=14)$ and receiving $(n=11)$ immediate feedback for a successful language learning process. Additionally, they reported that teachers would not have any opportunities to recognize their mistakes immediately while recording the courses on their own and modify their input accordingly:

"Teachers are not able to get instant feedback from students; they may not be able to detect the phrases or activities that need further explanation for pupils..." (Ecem)

Concerning the teachers' competencies, the student teachers pointed out that teachers were in a position that required to be digitally literate immediately $(n=6)$ and capable of integrating four skills successfully $(n=5)$ to teach in front of the cameras. They also expressed the importance of teachers' pronunciation skills in order not to cause any fossilized mistakes difficult to rehabilitate in the future:

"The teachers should pay close attention to their pronunciation while in front of the screen because many students watch them, and the mistake of the teachers can cause many students to learn wrong pronunciation" (Mehtap)

Student teachers were also concerned about such context-dependent factors as learning in a distracting environment $(n=16)$, students' technological constraints $(n=14)$, their unfamiliarity with distance learning $(n=10)$, their parents' negative attitude towards teaching English or distance learning $(n=3)$. Some of them verbalized that students needed to be alone to concentrate on the courses easily whereas others indicated that their parents should accompany them in case they might feel alone or comfortable. If they felt comfortable and relaxed, they might not have a desire to complete their assignments. 
"The disciplined atmosphere that the schools have may not be created at home, which possibly will result in lack of motivation if the families have little children or babies, the students probably will have concentration problems because of the noisy" (Azra)

Self-efficacy beliefs: "We can teach English successfully if we feel supported..."

As previously mentioned, self-efficacy beliefs refer to individuals' beliefs in their own capacity and their persistence to achieve a challenging task. Nearly twenty student teachers held positive self-efficacy beliefs, and they were optimistic that they would teach English successfully through distance learning:

"We don't know what the future holds, so we need to make all the improvements we can make in the field to provide a better education" (Beren)

"Teachers should be prepared for every condition and should know how to renew themselves." (Özge)

"These days have taught us that we have to improve ourselves as an individual and as a future teacher. We should learn new strategies for teaching and add more things to our teaching skills. (Defne)"

These student teachers sounded more likely open to change, flexible and resilient. To wit, they could positively adapt to the changing situations and teaching in every condition:

Looking at the current situation, it is easy to realize that there may arise many problems. But the thing is the ability to come up the obstacles. (Selen)

"This is change and change inevitable, we are living in 2020 and years ahead to come will only bring more such developments. In my opinion, this should be used as a stepping stone to boast [boost] ourselves into future. People are having a hard time realizing old methods are now obsolete and predated, and we the new generation of new era that is Technology Era should adapt. It wouldn't be surprising to see online education to replace the traditional education, so why don't we just use this golden opportunity. With what we know, and what we'll experience we can make it better, we can make it right." (Ipek)

As seen from the student teachers' excerpts, if they were expected to go through a necessary transformation, they would seem ready to make the necessary adjustments. They marked that they could teach English if they felt supported. We juxtaposed three contributing factors to their self-efficacy beliefs as studentoriented and teacher-oriented factors and parental involvement as tabulated in Table 2.

Table 2.

The distribution of the codes and categories and themes related to self-efficacy beliefs

\begin{tabular}{llll}
\hline Themes & Categories & Codes & $\begin{array}{l}\text { The } \\
(\mathbf{6 8})\end{array}$ \\
& & & 6 \\
& Student-oriented factors & Students' autonomy & 6 \\
& & Students' motivation & of \\
\cline { 2 - 4 } Self-efficacy \\
\cline { 2 - 4 } beliefs & Parental involvement & Creating a suitable learning environment & 11 \\
& & Monitoring students & 10 \\
& & Motivating students & 6 \\
& & Developing students' autonomy & 3 \\
\cline { 2 - 4 } & Teacher-oriented factors & Collaborating with parents and students & 14 \\
& & Using various and interactive activities & 12 \\
\hline
\end{tabular}

The student teachers enunciated that they could teach English once their students were motivated and autonomous. In fact, to be able to teach English successfully, nearly half of the student teachers in total $(\mathrm{n}=$ 29 ) voiced that they heavily relied on parental involvement and support one way or another. They marked that parents should consider the children's needs, encourage them to learn more, and create a silent, comfortable and suitable learning environment by eliminating the factors that distracted their attention: 
"The change of educational environment might harm students' motivation. For this reason, the parents need to manage the process effectively and make the situation as clear as possible for their children. it is essential for parents to prepare a convenient atmosphere so that the students can be easily adapted to the process." (Dicle)

They further verbalized that parents played an important role not only in motivating but also in monitoring the children's learning process:

“...parents should also monitor their child's process and participate in their lessons and assignments willingly.” (Damla)

\section{"Students can only study more precisely by the help of supervision of the parents." (Nil)}

In accordance with teacher-oriented factors, unlike some student teachers $(n=12)$ who pronounced that it was not possible to develop speaking skills in distance learning as mentioned above, fortunately twelve student teachers expressed that actual classroom teachers could facilitate language learning process by using various tools and activities such as web 2.0 tools, e-portfolio systems, online group projects:

"Students might feel alone. Thus, providing feedback and quick answers to their questions may be helpful to engage them in the learning. Furthermore, teachers need to build a sense of classroom community among students. There must be a space for students to get connected with one another. Discussions, online group projects, chats and virtual tools such as zoom app and other tools might boost a sense of real classroom". (Afra)

Some student teachers $(n=14)$ epitomized the importance of teachers' collaboration with parents and students in providing immediate feedback if necessary, informing both of them about the learning process, supporting the learning process as well as having an understanding attitude:

"Parents, students and teacher all should try to cooperate with each other and they all should take responsibility for both learning and teaching. " (Gül)

The findings of this study showed that the student teachers held a bunch of task-related concerns including macro-level factors and pedagogical issues, which need to be resolved for an effective teaching and learning process. These findings tallied somewhat with those in Boz (2008), who provided further evidence that student teachers' task concerns were high in a teacher education program in Turkey. Moreover, a great majority of student teachers shared high levels of impact concerns, including pedagogical issues and context-dependent factors. More specifically, student teachers were mainly concerned about controlling students' behaviors in terms of drawing their attention, motivating them when they get side-tracked, and monitoring their active participation, meaning that student teachers paid close attention to the pupils' emotional and social needs. Succinctly, student teachers' impact concerns were higher than their selfconcerns, indicating that they took pupils' emotional and social needs into account. This finding might be attributed to the fact that student teachers could be sympathizing with the pupils because they somehow went through similar learning processes and experience challenges more or less. Additionally, they evaluated other teachers' performance, which unfortunately could have limited the opportunity of reflecting on their own survival in the class. Nevertheless, these findings were consistent with those found in Reeves and Kazelskis (1985), O'Connor and Taylor (1992), and Swennen and her colleagues (2004) who indicated high levels of impact concerns among student teachers. Besides, the findings run counter to developmental stages in Fuller's (1967) model whereas they reinforced the findings of several previous studies (e.g., Reeves \& Kazelski, 1985; Pigge and Marso, 1997; Boz, 2008) by indicating that the student teachers had developed different teaching concerns simultaneously rather than sequentially.

It is noteworthy that limited social interaction concerned a great majority of student teachers as. In a very recent study, Hebebci et al. (2020) similarly proved that both students and teachers were concerned about the lack of interaction and communication due to the asynchronous nature of EBA TV. In addition, student 
teachers had a right to bemoan this constraint since it has been a well-established fact in the literature that social interaction yields to language development ipso facto (Vygotsky, 1962, 1978). Overall, we stand at the threshold of understanding student teachers' concerns to relieve them for the future in case distance learning platforms might topple the long-standing sovereignty of traditional education soon. Even if it does not supplant it, it will supplement the traditional education in a better scenario. Parallel to this aim, teacher educators need to prepare teachers for the future by developing their online teaching competencies as also argued in Atmojo and Nugroho (2020) and Bailey and Lee (2020) by enhancing student teachers' selfefficacy beliefs. In addition, self-efficacy beliefs should be enhanced since teachers with higher selfefficacy beliefs might "invite and receive more parent involvement..." (Hoover-Dempsey et al. 1992, p. 292).

Additionally, as revealed by their utterances, some student teachers with lower self-efficacy beliefs interestingly shared the concern that parents should take responsibility for their children's learning process. They regarded the parents as the authority figures and seemed to favor helicopter parenting, i.e., "overcontrolling parenting" (Schiffrin et al., 2014, p. 548), over autonomy-supportive parenting. Although this distance education process emerged as a novel and compulsory practice, it might nudge both teachers and parents into the point that they should abandon the role of helicopter parenting since it may harm students' well-being and lead them to depression (Schiffrin et al., 2014). Otherwise, we might not be able to raise self-regulated and autonomous children. On the other hand, only a few student teachers with higher selfefficacy beliefs underscored the importance of raising autonomous children for the efficacy of distance education. In fact, it is a well-established fact in the literature that the success of online or distance education depends on by and large learner autonomy. As also stipulated by Moore (1972), learner autonomy should be emphasized more on a par with the lower level of dialogue.

Nevertheless, the overall findings showed that their concerns outweighed their perceived self-efficacy beliefs, and they mostly attributed their success to -rightly or wrongly- external factors such as parental involvement and classroom teachers' support. They sounded plausible in that "collaboration and communities of practice reduce the sense of isolation and the feeling that students are facing the world of learning alone" (Nunan, 2012, p. xi) in distance learning. The findings unfold that student teachers' selfefficacy beliefs could be enhanced through collaboration with others since distance learning platforms are beset with some constraints such as lack of interaction and lack of opportunities for providing immediate feedback and implementing production-based activities as also reiterated in Todd (2020), Erarslan (2021), and Hazaea et al. (2021).

Last but certainly not least, 'The Future of Education and Skills: Education 2030' report released by the Organisation for Economic Co-operation and Development (OECD, 2018) accentuated that new jobs would be created, and new technologies would appear in ten years. Grappling with this uncertainty and complexity, schools should prepare individuals who "develop curiosity, imagination, resilience and selfregulation" (OECD, 2018, p. 2) to find solutions to challenging problems. Therefore, teachers might need to be less worried but more resilient and reinforce their students' self-efficacy beliefs, self-regulation and autonomy, which are closely related to each other. As Bandura (2012) marked, self-efficacy beliefs could be "strengthened by reducing anxiety and depression, building physical strength and stamina, and correcting the misreading of physical and emotional states" (p. 13).

\section{Conclusion and Suggestions}

This study attempted to unveil student teachers' concerns and self-efficacy beliefs about teaching English through EBA TV. Based on the findings of the study, we can claim that teachers' concerns about teacher competencies might bring their tacit self-concerns to the fore; as such, they are hopefully aware that teachers need to improve certain skills in order to survive as a teacher in such a platform. We believe that realizing the importance of these qualities in the first place could be a poignant way of improving them in the future. Even though student teachers' beliefs and concerns might not automatically transfer into their actual 
classroom practices, the findings provide an insight into their feelings for further support and guidance in order to boost resilient self-efficacy beliefs for the future. Thus, we hope these findings could galvanize teacher educators to relieve student teachers' concerns about distance learning by helping them develop their digital identities rather than blind obedience to the traditional classes. Likewise, teacher educators should help individuals become cognizant of their own concerns to develop their teaching competencies and professional identities or mission (Korthagen, 2004). Additionally, it is noteworthy to mull over the opportunities for designing and practicing online tools to supplement distance education in order to enhance student teachers' sense of efficacy. Enhancing their sense of efficacy is of pivotal importance for them to raise students with higher self-efficacy beliefs in the future since, as teachers, "consciously, we teach what we know; unconsciously, we teach who we are" (Hamachek, 1999, p. 209).

Succinctly, the findings of the present study portrayed the current situation of teaching English through distance learning. Rather than plunging into teaching English behind the scenes, now we have a chance to hone the challenging points into advantages. Nevertheless, we should note that equally important to having an insight into these points is directing student teachers to get them through immediately, if possible. Nevertheless, the present study is a cross-sectional study, and these findings constitute only a rudimentary framework for student teachers' feelings about a distance education platform. Therefore, teacher concern and self-efficacy beliefs warrant further in-depth explorations, especially by employing in-service teachers.

\section{References}

Atmojo, A. E. P., \& Nugroho, A. (2020). EFL classes must go online! Teaching activities and challenges during COVID-19 pandemic in Indonesia. Register Journal, 13(1), 49-76. https://doi.org/10.18326/rgt.v13i1.49-76

Bailey, D. R., \& Lee, A. R. (2020). Learning from experience in the midst of COVID 19: Benefits, challenges, and strategies in online teaching. Computer-Assisted Language Learning Electronic Journal, 21(2), 178-198.

Bandura, A. (1986). Social foundations of thought and action: A social cognitive theory. Englewood Cliffs, NJ: Prentice Hall

Bandura, A. (2000). Exercise of human agency through collective efficacy. Current Directions in Psychological Science, 9, 75-78. https://doi.org/10.1111/1467-8721.00064

Bandura, A. (2012). On the functional properties of perceived self-efficacy revisited. Journal of Management. (38)1, 9-44.

Boz, Y. (2008). Turkish student teachers' concerns about teaching. European Journal of Teacher Education, 31(4), 367-377. https://doi.org/10.1080/02619760802420693

Boz, Y., \& Boz, N. (2010). The nature of the relationship between teaching concerns and sense of efficacy. European Journal of Teacher Education, 33(3), 279-291. https://doi.org/10.1080/02619768.2010.490910

Bozkurt, A., \& Sharma, R. C. (2020). Emergency remote teaching in a time of global crisis due to CoronaVirus pandemic. Asian Journal of Distance Education, 15(1), i-vi.

Brouwers, A., \& Tomic, W. (2000). A longitudinal study of teacher burnout and perceived self-efficacy in classroom management. Teaching and Teacher Education, 16(2), 239-253. https://doi.org/10.1016/S0742-051X(99)00057-8

Burn, K., Hagger, H., Mutton, T., \& Everton, T. (2003). The complex development of student- teachers' thinking. Teachers and Teaching, 9(4), 309-331. https://doi.org/10.1080/1354060032000097235 
Butler, E. D., \& Smith, D. L. (1989). A study of factors associated with fifth-year teacher interns' concerns, problems, and stress. Paper presented at the annual meeting of the American Educational Research Association, San Francisco, CA. https://files.eric.ed.gov/fulltext/ED309157.pdf

Coladarci, T. (1992). Teachers' sense of efficacy and commitment to teaching. The Journal of Experimental Education, 60(4), 323-337.

Demir, S. (2020). The role of self-efficacy in job satisfaction, organizational commitment, motivation and job involvement. Eurasian Journal of Educational Research, 85, 205-224.

Erarslan, A. (2021) English language teaching and learning during Covid-19: A global perspective on the first year. Journal of Educational Technology and Online Learning, 4(2), 349-367. https://doi.org/10.31681/jetol.907757

Farmer, T., \& West, R. (2019). Exploring the concerns of online K-12 teachers. Journal of Online Learning Research, 5(1), 97-118. https://www.learntechlib.org/p/184482/

Fuller, F. (1969). Concerns of teachers: A developmental conceptualization. American Educational Research Journal, 6(2), 207-226.

Fuller, F. F., \& Bown, O. H. (1975). Becoming a teacher. In Ryan, K., (Ed.), Teacher Education. (74th ed., pp. 25-52). Chicago: University of Chicago Press.

Fuller, F. F., Parsons, J. S., \& Watkins, J. E. (1974). Concerns of teachers: Research and reconceptualization. Austin: University of Texas Research and Development Center for Teacher Education.

Gibbs, S., \& Miller, A. (2014). Teachers' resilience and well-being: A role for educational psychology. Teachers and Teaching, 20(5), 609-621. https://doi.org/10.1080/13540602.2013.844408

Gibson, S., \& Dembo, M. H. (1984). Teacher efficacy: A construct validation. Journal of Educational Psychology, 76, 569-582.

Glickman, C. D., \& Tamashiro, R. T. (1982). A comparison of first-year, fifth-year, and former teachers on efficacy, ego development, and problem solving. Psychology in the Schools, 19(4), 558-562.

Guillaume, A., and G. Rudney. (1993). Student teachers' growth toward independence: an analysis of their changing concerns. Teaching and Teacher Education, 9(1), 65-80. https://doi.org/10.1016/0742$\underline{051 X(93) 90015-9}$

Hamachek, D. (1999). Effective teachers: What they do, how they do it, and the importance of selfknowledge. In R. P. Lipka, \& T. M. Brinthaupt (Eds.), The role of self in teacher development (pp. 189-224). Albany, NY: State University of New York Press.

Hargreaves, A. (1998). The emotional practice of teaching, Teaching and Teacher Education, 14(8), 835854.

Hargreaves, A. (2000). Mixed emotions: teachers perceptions of their interactions with students, Teaching and Teacher Education, 16(8), 811-826.

Hazaea, A. N., Bin-Hady, W. R. A., \& Toujani, M. M. (2021). Emergency remote English language teaching in the Arab league countries: Challenges and remedies. Computer-Assisted Language Learning Electronic Journal, 201-222.

Hebebci, M. T., Bertiz, Y., \& Alan, S. (2020). Investigation of views of students and teachers on distance education practices during the Coronavirus (COVID-19) Pandemic. International Journal of Technology in Education and Science (IJTES), 4(4), 267-282. 
Heidari, F., Nourmohammadi, E., \& Nowrouzi, H. (2012). On the relationship between Iranian EFL teachers' self-efficacy beliefs and their teaching styles. International Journal of Linguistics, 4(3), 536-550. http://dx.doi.org/10.5296/ijl.v4i3.2089

Hodges, C. B., Moore, S., Lockee, B. B., Trust, T., \& Bond, M. A. (2020). The difference between emergency remote teaching and online learning. EDUCAUSE Review. https://er.educause.edu/articles/2020/3/the-difference-between-emergency-remote-teaching-andonline-learning

Hong, J. Y. (2012). Why do some beginning teachers leave the school, and others stay? Understanding teacher resilience through psychological lenses. Teachers and Teaching, 18(4), 417-440. https://doi.org/10.1080/13540602.2012.696044

Hoover-Dempsey, K. V., Bassler, O. C., \& Brissie, J. S. (1987). Parent involvement: Contributions of teacher efficacy, school socioeconomic status, and other school characteristics. American Journal of Educational Research, 24, 417-435. https://doi.org/10.3102/00028312024003417

Hoover-Dempsey, K. V., Bassler, O. C., \& Brissie, J. S. (1992). Explorations in parent-school relations. The Journal of Educational Research, 85(5), 287-294. https://doi.org/10.1080/00220671.1992.9941128

Kasalak, G., \& Dagyar, M. (2020). The relationship between teacher self-efficacy and teacher job satisfaction: A Meta-analysis of the teaching and learning international survey (TALIS). Educational Sciences: Theory and Practice, 20(3), 16-33.

Korthagen, F. (2004) In search of the essence of a good teacher: towards a more holistic approach in teacher education, Teaching and Teacher Education, 20(1), 77-97.

Krippendorff, K. (2018). Content analysis: An introduction to its methodology. Thousand Oaks, CA: Sage publications.

Meijer, P. C., Korthagen, F. A., \& Vasalos, A. (2009). Supporting presence in teacher education: The connection between the personal and professional aspects of teaching. Teaching and Teacher Education, 25(2), 297-308.

Merriam, S. B. (2002). Qualitative research in practice: Examples for discussion and analysis. San Francisco, CA: Jossey-Bass.

Moore, M. G. (1972). Learner autonomy: The second dimension of independent learning. Convergence, 5(2), 76.

Nunan, D. (2012). 'Foreword' in L. England (ed.). Online language teacher education: TESOL Perspectives. London: Routledge, pp. vii-xiv.

O'Connor, J., \& Taylor, H. P. (1992). Understanding preservice and novice teachers' concerns to improve teacher recruitment and retention. Teacher Education Quarterly, 19-28. https://www.jstor.org/stable/23475651

OECD. (2018). The future of education and skills: Education 2030. Retrieved from https://www.oecd.org/education/2030/E2030\%20Position\%20Paper\%20(05.04.2018).pdf

Pigge, F. L., \& Marso, R. N. (1997). A seven year longitudinal multi-factor assessment of teaching concerns development through preparation and early years of teaching. Teaching and Teacher Education, 13(2), 225-235. https://doi.org/10.1016/S0742-051X(96)00014-5

Poulou, M. (2007). Student-teachers' concerns about teaching practice. European Journal of Teacher Education, 30(1), 91-110. https://doi.org/10.1080/02619760600944993 
Reeves, C. K., \& Kazelskis, R. (1985). Concerns of preservice and inservice teachers. The Journal of Educational Research, 78(5), 267-271. https://doi.org/10.1080/00220671.1985.10885614

Schiffrin, H. H., Liss, M., Miles-McLean, H., Geary, K. A., Erchull, M. J., \& Tashner, T. (2014). Helping or hovering? The effects of helicopter parenting on college students' well-being. Journal of Child and Family Studies, 23(3), 548-557.

Sosa, T., \& Gomez, K. (2012). Connecting teacher efficacy beliefs in promoting resilience to support of Latino students. Urban Education, 47(5), 876-909. https://doi.org/10.1177/0042085912446033

Swennen, A., Jörg, T., \& Korthagen, F. (2004). Studying student teachers' concerns, combining imagebased and more traditional research techniques. European Journal of Teacher Education, 27(3), 265-283. https://doi.org/10.1080/0261976042000290796

Todd, R. W. (2020). Teachers' perceptions of the shift from the classroom to online teaching. International Journal of TESOL Studies, 2(2), 4-17.

Usher, E. L., \& Schunk, D. H. (2018). Social cognitive theoretical perspective of self-regulation. In D. H. Schunk \& J.A. Greene (Eds.), Handbook of self-regulation of learning and performance ( $2^{\text {nd }}$ ed., pp. 19-35). New York: Routledge, Taylor \& Francis.

Vygotsky, L. S. (1962). Thought and language. Cambridge: The MIT Press

Vygotsky, L. S. (1978). Mind in society: The development of higher psychological processes. USA: Harvard University Press

\section{Appendix A}

Links to the English courses student teachers are assigned to watch have been provided below.

https://www.trtizle.com/sinif3/3-sinif-ingilizce/ders-3-transportation-1-1803679

https://www.trtizle.com/sinif4/4-sinif-ingilizce/ders-2-my-clothes-1-1802295

https://www.trtizle.com/sinif7/7-sinif-ingilizce/ders-3-public-buildings-1-1810134 